\title{
Antibacterial activity of artocarpanone isolated from Artocarpus heterophyllus heartwoods against diarrheal pathogens and its mechanism of action on membrane permeability
}

\author{
Abdi Wira Septama ${ }^{1 *}$, Pharkphoom Panichayupakaranant ${ }^{2}$ \\ ${ }^{1}$ Faculty of Medicine, Universiti Sultan Zainal Abidin, Jalan Sultan Mahmud 20400, Kuala Terengganu, Terengganu, Malaysia. \\ ${ }^{2}$ Department of Pharmacognosy and Pharmaceutical Botany, Faculty of Pharmaceutical Sciences, Prince of Songkla University, \\ Hat Yai, Songkhla 90112, Thailand.
}

\section{ARTICLE INFO}

Article history:

Received on: 24/07/2017

Accepted on: 17/09/2017

Available online: 30/11/2017

\section{Key words:}

Antibacterial, Artocarpus heterophyllus, artocarpanone, flavonoid, Escherichia coli, membrane permeability.

\begin{abstract}
Artocarpus heterophyllus has been used as ingredient of folk medicine. Artocarpanone isolated from the heartwood of A. heterophyllus exhibited an antibacterial activity. The present study was undertaken to investigate its activity against diarrheal pathogenic bacteria including Escherichia coli, Vibrio cholera, Shigella sonnei, Salmonella typhimurium, and S. typhi. The effect of this compound on membrane permeability was also evaluated. Broth microdilution was used to determine antibacterial activity. Time-kill assay was selected to confirm any bactericidal activity. Bacteriolysis assay and loss of $260 \mathrm{~nm}$ absorbing material were used to assess the alteration on membrane cell. Artocarpanone displayed strong antibacterial activity against $E$. coli with MIC and $\mathrm{MBC}$ value of 3.9 and $7.8 \mu \mathrm{g} / \mathrm{mL}$, respectively. Time-kill curve also confirmed the bactericidal activity of this compound. Artocarpanone only showed moderate antibacterial activity against $V$. cholera and did not perform any activity against $S$. typhimurium, and $S$. typhi. Supra-MIC $(4 \times$ MIC) of artocarpanone was able to decrease membrane permeability of $E$. coli after $24 \mathrm{~h}$ incubation and lead cell lysis. These results indicated that artocarpanone has potency as antibacterial against $E$. coli by altering membrane cell.
\end{abstract}

\section{INTRODUCTION}

Diarrhea is a still a major public health problem which lead to millions death worldwide. It has been reported that up to $80 \%$ of mortality occur in Africa and South Asia countries (Ibrahim and Sarhan, 2015). In microbiological aspect, the disease was caused by bacterial infection such as Escherichia coli, Vibrio cholera, and Salmonella sp (Huang et al., 2002; Holland, 1990). E. coli is a Gram-negative pathogenic bacterium

\section{* Corresponding Author}

Abdi Wira Septama, Faculty of Medicine, Universiti Sultan Zainal Abidin, Jalan Sultan Mahmud 20400, Kuala Terengganu, Terengganu, Malaysia. Tel/Fax. 60-0109379287;

E-mail: abdiwiraseptama @ gmail.com which is a major cause of gastrointestinal tract infection (Ganapathy and Kapargam, 2016). Enterotoxigenic E. coli (ETEC) play an important role to cause diarrhea in human. Moreover, cholera toxin derived from $V$. cholera is also linked with the disease (Dubreuli, 2013). Antibiotic was commonly used as a principle management for diarrhea. However, the agent only kills suspected bacteria without inhibiting bacterial toxins. The use of antibiotics also leads to the increase of resistance toward antibiotics (Clatworthy, 2007). Thus, it needs to find the alternative strategy to overcome this problem.

Natural product is a potential source for the discovery of alternative medicine including antibacterial compounds. In case of diarrhea problems, world health organization (WHO) has encouraged several studies for the treatment and prevention of the disease using medicinal plants (WHO, 2005). 
It has been reported that several plants extract such as Ocimum bacilisum, O. gratissimum, Hibiscus sabdarifa, and Adansania digitate possessed antibacterial activities against diarrheal pathogens (Ibrahim and Sarhan, 2015; Djeusi et al., 2013). Artocarpus heterophyllus Lam. has been used as a folk medicine in Asia for the treatment of ailments including bacterial infection (Saxena et al., 2009). This plant was also known as an important source of flavonoid compounds (Arung et al., 2006). Artocarpanone (Fig. 1) is an isolated flavonoid from the heartwoods of A. heterophyllus. This compound possessed many pharmacological properties such as anti-tyrosinase, antiinflammation, and antioxidant (Dej-Adisai et al., 2014; Arung et al., 2010). Previously, it has been reported that artocarpanone had antibacterial activity against several pathogenic bacteria (Septama and Panichayupakaranant, 2015). Little information is available about the effect of this compound against diarrheal pathogenic bacteria. Thus, the aims of this study are to determine the antibacterial activity of artocarpanone against several enterophatogenic bacteria as well as to investigate its mechanisms of action on membrane permeability.

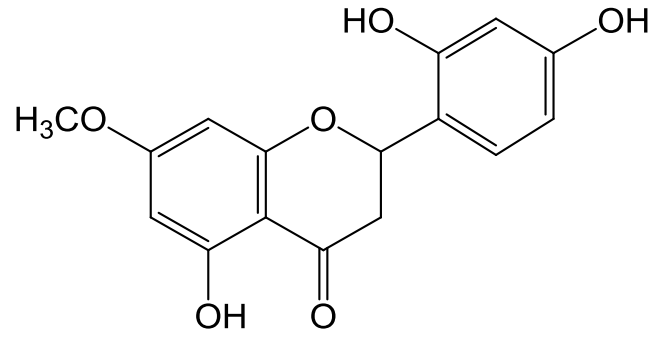

Fig. 1: Chemical structure of artocarpanone.

\section{MATERIALS AND METHODS}

\section{Chemicals}

Artocarpanone was isolated from the active fraction of Artocarpus heterophyllus heartwoods as previously described (Septama and Panichayupakaranant, 2015). Ampicillin was from Sigma (Sigma-Aldrich, UK). Brain heart infusion (BHI) and agar were from the Becton, Dickinson and Company (Franklin Lakes, $\mathrm{NJ})$.

\section{Bacterial strains}

Escherichia coli (ATCC 25922), Vibrio cholera (ATCC 14035), Shigella sonnei (ATCC 29930), Salmonella typhimurium (ATCC 29630), and Salmonella typhi (ATCC 19430) were obtained from the Department of Medical Sciences, Ministry of Public Health, Thailand.

\section{Determination of minimum inhibitory concentrations}

The minimum inhibitory concentration (MIC) and minimal bactericidal concentration (MBC) was determined using the broth microdillution assay (NCCLS, 2008). The sample was initially dissolved in DMSO, and subsequently in media broth to reach a desired final concentration. Two fold dilutions were prepared in 96 -well plate, $100 \mu \mathrm{L}$ of working solution was added into well 1 of dilution series, each remaining plate were added 50 $\mu \mathrm{L}$ broth. Further, $50 \mu \mathrm{L}$ solution from well 1 were transferred into well 2 and mix the solution. After that, $50 \mu \mathrm{L}$ solutions from well 2 were transferred into well 3 , and this process was continued until the last final concentration was obtained. Well 12 as a growth control, receive no sample or antibacterial agent. Bacteria suspension was prepared in normal saline solution (NSS) adjusted to $10^{8} \mathrm{CFU} / \mathrm{mL}$ with turbidity of $0.5 \mathrm{McFarland}$ standards. The bacteria suspension was diluted $(1: 100)$ with NSS to contain approximately $10^{6} \mathrm{CFU} / \mathrm{mL}$, then $50 \mu \mathrm{L}$ bacteria suspension was added into each well and then incubated under the suitable conditions.

The MIC was considered as the lowest concentration of sample that prevented visible growth. Meanwhile, the MBC was detected as the lowest concentration, which no colonies of test bacteria formed on the cultivation medium

\section{Time kill assay}

Time kill assay was used to observe bactericidal activity of compounds against tested bacteria. Bacterial suspension in normal saline $\left(1 \times 10^{6} \mathrm{CFU} / \mathrm{ml}\right)$ was added into BHI broth containing compounds at $1 / 2 \times \mathrm{MIC}$, MIC, $2 \times \mathrm{MIC}$ and $4 \times \mathrm{MIC}$ to reach final concentration $\left(5 \times 10^{5} \mathrm{CFU} / \mathrm{mL}\right)$ and incubated at $37^{\circ} \mathrm{C}$. Next, $50 \mu \mathrm{L}$ of culture were collected at several time intervals $(0$, $1,2,4,6,8,12$ and $24 \mathrm{~h}$ ), then diluted with $450 \mu \mathrm{L}$ of normal saline. Afterward, $10 \mu \mathrm{L}$ of bacterial suspension from each serial dilution was added on BHI agar. The surviving bacteria were then incubated. The numbers of viable colonies were then calculated after $24 \mathrm{~h}$ incubation (Hamoud et al., 2014).

\section{Bacteriolysis}

The modified method was used to detect the bacteriolysis activity (Limsuwan et al., 2012). Briefly, bacterial suspension was prepared from the overnight culture on BHI agar. The cells were then supplemented with various concentrations of compound at $1 / 2$ $\times$ MIC, MIC, $2 \times$ MIC and $4 \times$ MIC. The final concentration was 5 $\times 10^{7} \mathrm{CFU} / \mathrm{mL}$. The cell without treatment was used as control. Afterwards, the cells were incubated at $37^{\circ} \mathrm{C}$. The optical density at $620 \mathrm{~nm}$ (OD620) was taken at several times interval $(0,1,2,4$, $6,8,12$ and $24 \mathrm{~h}$ ). Bacteriolysis was indicated by decreasing of absorbance at $620 \mathrm{~nm}$. The results were a percentage of OD620 at each time versus OD620 a $0 \mathrm{~h}$. The test was done in triplicate.

\section{Loss of $260 \mathrm{~nm}$ absorbing material}

The release of UV-absorbing material was carried out as described previously with slight modifications (Limsuwan et al., 2012) Overnight cultures of tested bacteria were washed and suspended in normal saline. Various concentrations of the compound at $1 / 2 \times$ MIC, MIC, $2 \times$ MIC and $4 \times$ MIC were added into the cell to reach the final count approximately $5 \times 10^{7}$ $\mathrm{CFU} / \mathrm{mL}$.

The cell without treatment was used as control. All the samples were then incubated at $37^{\circ} \mathrm{C}$. The cells were removed at 0 , $1,2,4,6,8,12$ and $24 \mathrm{~h}$, then diluted with normal saline (1:100) 
and filtered through a $0.2 \mu \mathrm{m}$ pore-size filter. The optical density at $260 \mathrm{~nm}$ was UV-Vis spectrophotometer. This assay was performed in triplicate.

\section{Statistical analysis}

Data are presented as average value and standard deviation. Data were analyzed using ANOVA for multiple comparison, followed by Tukey's HSD post hoc test denoted the presence of a statistically significant difference. $P<0.01$ was considered as statistically significant.

\section{RESULTS AND DISCUSSION}

Antibacterial activity of artocarpanone and antibiotic against diarrhea pathogenic bacteria were presented as MIC and MBC (Table 1). Artocarpanone exhibited the strongest antibacterial activity against $E$. coli with MIC value of $3.9 \mu \mathrm{g} / \mathrm{mL}$ and $\mathrm{MBC}$ value of $7.8 \mu \mathrm{g} / \mathrm{mL}$. This compound only had weak activity against $V$. cholerae and $S$. sonnei with MIC values of 62.5 and $250 \mu \mathrm{g} / \mathrm{mL}$, and MBCs of 62.5 and $250 \mu \mathrm{g} / \mathrm{mL}$, respectively. However, artocarpanone had no effects against $S$. typhi and $S$. typhimurium. On the other hand, ampicillin also showed strong antibacterial activity against $E$. coli with MIC value of $0.9 \mu \mathrm{g} / \mathrm{mL}$, and $\mathrm{MBC}$ value of $1.95 \mu \mathrm{g} / \mathrm{mL}$. This reference antibiotic only produced moderate antibacterial activity against $V$. cholerae, $S$. Sonnei, S. typhi and S. typhimurium with MIC values of 62.5 -125 $\mu \mathrm{g} / \mathrm{mL}$, and $\mathrm{MBC}$ values of $125-250 \mu \mathrm{g} / \mathrm{mL}$. The results revealed that $E$. coli was more sensitive to artocarpanone, therefore this bacteria was selected for further experiments.

Table 1: MIC and MBC values of artocarpanone and ampicillin.

\begin{tabular}{ccccc}
\hline & \multicolumn{2}{c}{ Artocarpanone } & \multicolumn{2}{c}{ Ampicillin } \\
& $\begin{array}{ccc}\text { MIC } \\
(\boldsymbol{\mu g} / \mathbf{m L})\end{array}$ & $\begin{array}{c}\text { MBC } \\
(\boldsymbol{\mu g} / \mathbf{m L})\end{array}$ & $\begin{array}{c}\text { MIC } \\
(\boldsymbol{\mu g} / \mathbf{m L})\end{array}$ & $\begin{array}{c}\text { MBC } \\
(\boldsymbol{\mu g} / \mathbf{m L})\end{array}$ \\
\hline E. coli & 3.9 & 7.8 & 0.9 & 1.95 \\
V. cholera & 62.5 & 62.5 & 62.5 & 62.5 \\
S. sonnei & 250 & 250 & 62.5 & 62.5 \\
S. typhi & 500 & $>500$ & 125 & 125 \\
S. typhimurium & 500 & $>500$ & 125 & 125 \\
\hline
\end{tabular}

Time kill assay was performed to confirm bactericidal activity of artocarpanone against $E$. coli. Four serial concentrations were used. The killing curve of tested bacteria after treatment with compounds was demonstrated in Fig. 2. It was observed that artocarpanone at $4 \times$ MIC, completely inhibited the bacterial growth within $6 \mathrm{~h}$ incubation, which is comparable to the activity of ampicillin showing growth inhibitionof $E$. coli within $4 \mathrm{~h}$. This indicated that artocarpanone at supra-MIC $(4 \times \mathrm{MIC})$ had powerful antibacterial activity against $E$. coli. Artocarpanone at $2 \times \mathrm{MIC}$ and MIC only inhibited the bacterial growth after $24 \mathrm{~h}$ incubation. It has been reported that artocarpanone had satisfactory antibacterial activity against several bacteria including E. coli (Septama and Panichayupakaranant, 2015).This compound also enhanced the antibacterial activity of norfloxacin by altering membrane permeability of MRSA (Septama et al., 2017).

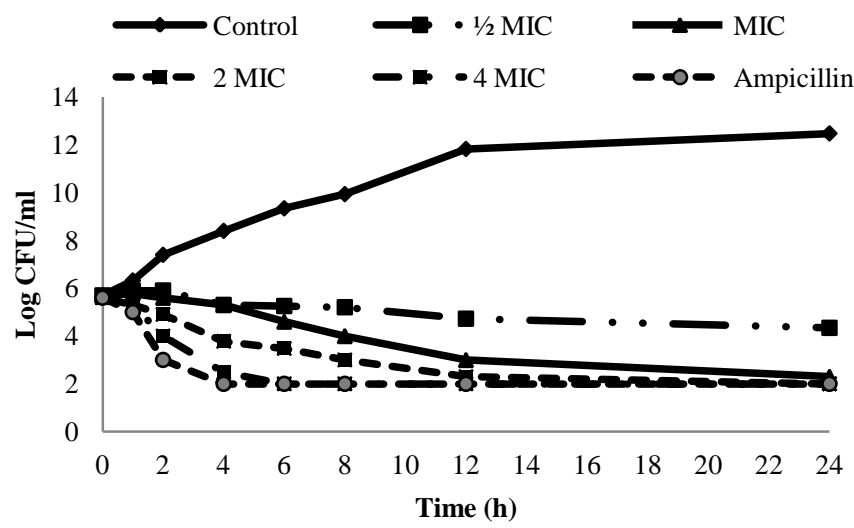

Fig. 2: Time-kill curves of artocarpanone and ampicillin against $E$. coli.

It has been known the Gram-negative bacteria are surrounded by outer membrane which providesa selective barrier to protect the cell from harmful agents (Lambert, 2002). These bacteria were also difficult to control using commercial antibiotics due to the low permeability on their membrane. Cell membrane alteration is one of the mechanisms of action of flavonoid (Tsuchiya and Iinum, 2000). Therefore, this study also focused on exploring the alteration of membrane permeability by artocarpanone. According to bacteriolysis assay, the result showed that artocarpanone at $4 \times$ MIC and $2 \times$ MIC generated bacteriolytic effect after 24 h (Fig.3). Compound at MIC and $1 / 2 \times$ MIC had no effect on membrane permeability. The experiment was then confirmed by measuring release of absorbing materials as an indicator of cytoplasmic membrane leakage (Oonmetta-aree et al., 2006). As shown in Fig. 4, after $24 \mathrm{~h}$ incubation, the absorbance of artocarpanone at $4 \times$ MIC was significantly higher than control. This result corresponded well with bacteriolytic activity. It indicated that artocarpanone may cause membrane cell disruption and release of intracellular material form including nucleic acid as well as ion from bacterial to cell environment.

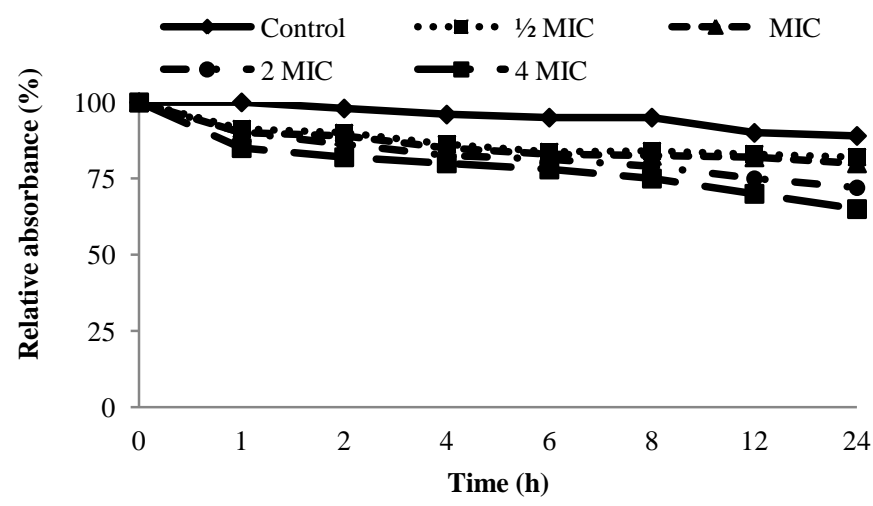

Fig. 3: Bacteriolytic activity of artocarpanone against E. coli. 


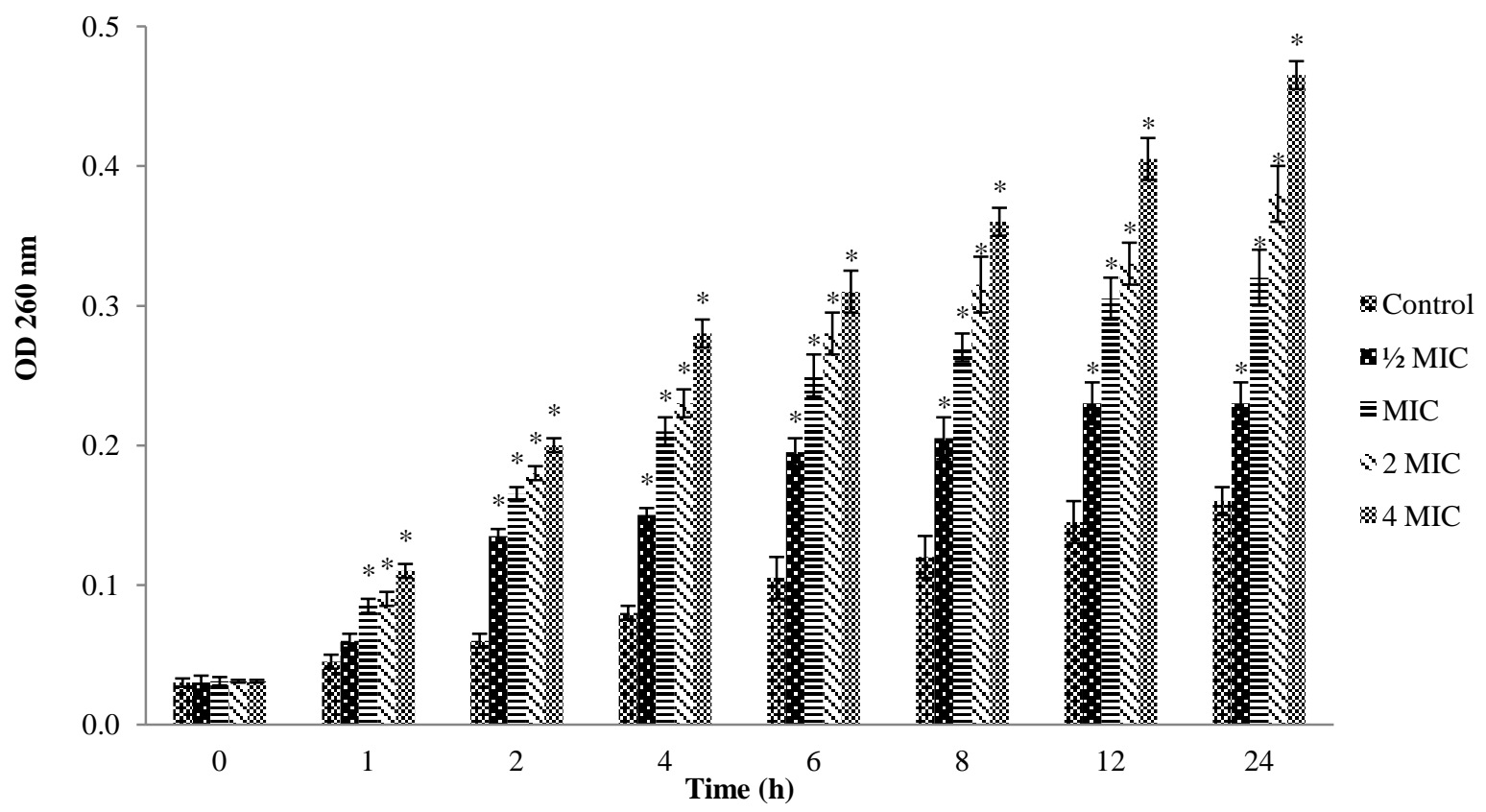

Fig. 4: Optical density (OD) $260 \mathrm{~nm}$ of $E$. coli treated with artocarpanone. * Significant difference $(P<0.01)$ compared to control.

Natural product has a promising prospect as a source of novel antibacterial agents which can be used to overcome resistant problem. Many isolated compounds including flavonoid had strong antibacterial activity. The mechanism of antibacterial action of isolated compound is still unclear. However, membrane cell is probably one of the sites of action (Cushnie and Lamb, 2011). It has been known that flavonoid may interact with lipophilic side of the Gram-negative bacteria. This interaction may reduce the membrane fluidity which causes cytoplasmic membrane damage (Hendrich, 2006). Some studies also suggested that the inhibition of synthesis of nucleic acid as well as energy metabolism as the target sites of flavonoid (Cushnie and Lamb, 2011). According to previous study, sophoraflavanone G isolated from Sophora exigua displayed an antibacterial activity against MRSA by decreasing membrane permeability (Mun et al., 2014). Study by Cushnie and Lamb showed that galangin induced the cytoplasmic membrane damage in Staphylococcus aureus (Cushnie and Lamb, 2005). In addition, quercetin also performed strong antibacterial activity against $E$. coli by increasing inner membrane permeability and dissipation of the membrane potential (Simoes et al., 2009).

\section{CONCLUSION}

In conclusion, artocarpanone displayed an antibacterial activity against $E$. coli by disrupting membrane permeability. This finding implied that artocarpanone enabled to inhibit the enterophatogenic bacteria and provide the evidence that this compound has a potency as antibacterial agent. Nevertheless, further investigations are still needed to elucidate the mechanism of action of artocarpanone towards diarrheal pathogenic bacteria including E. coli.

\section{ACKNOWLEDGEMENTS}

Authors thank to Prince of Songkla University and the Higher Education Research Promotion and National Research University Project of Thailand, Office of the Higher Education Commission, Thailand for providing the grant.

\section{REFERENCES}

Arung ET, Yoshikawa K, Shimizu K, Kondo R. Isoprenoidsubstituted flavonoids from wood of Artocarpus heterophyllus on B16 melanoma cells: Cytotoxicity and structural criteria. Fitoterapia, 2010; 81: 120-23.

Arung ET, Shimizu K, Kondo R. Inhibitory Effect of Artocarpanone from Artocarpus heterophyllus on Melanin Biosynthesis. Biol Pharm Bull, 2006; 29: 1966-1969.

Clatworthy AE, Pierson E, Hung DT. Targeting virulence: a new paradigm for antimicrobial therapy. Nat Chem Biol, 2007; 3: 541548.

Cushnie TPT, Lamb AJ. Recent advances in understanding the antibacterial properties of flavonoids. Int J Antimicrob Ag, 2011; 38: 99107.

Cushnie TPT, Lamb AJ. Detection of galangin-induced cytoplasmic membrane damage in Staphylococcus aureus by measuring potassium loss. J Ethnopharmacol,2005; 101: 243-248.

Dej-adisai S, Meechai I, Puripattanavong J. Kummee, S. Antityrosinase and antimicrobial activities from Thai medicinal plants Arch Pharm Res, 2014; 37: 473-83.

Djeusi DE, Noumedem JAK, Seukep JA, Fankam AG, Voukeng IK, Tankeo SB, Nkuete AHL, Kuete V. Antibacterial activities of selected edible plants extracts against multidrug-resistant Gram-negative bacteria. Evid Based Complement Alternat Med, 2013; 13: 164. 
Dubreuli JD. Antibacterial and antidiarrheal activities of plant products against enterotoxinogenic Escherichia coli. Toxins.2013; 5: 2009-2041.

Ganapathy S, Kapargam S. In vitro antibacterial and phytochemical potential of Aegle marmelos against multiple drug resistant (MDR) Escherichia coli. J Pharmacog Phytochem, 2016; 5: 253-255.

Hamoud R, Zimmermann S, Reichling J, Wink M. Synergistic interactions in two-drug and three-drug combinations (thymol, EDTA and vancomycin) against multi drug resistant bacteria including E. coli. Phytomedicine.2014; 21: 443-447.

Hendrich AB. Flavonoid-membrane interactions: possible consequences for biological effects of some polyphenolic compounds. Acta Pharm Sinic, 2006; 27: 27-40.

Holland RE. Some infectious causes of diarrhea in young farm animals. Clin Microbiol Rev, 1990: 345-375.

Huang JS, Bousvaros A, Lee JW, Diaz A, Davidson EJ. Efficacy of probiotic use in acute diarrhea in children: A meta-analysis. Diag Dis Sci, 2002; 47: 2625-2634.

Ibrahim OMS, Sarhan SR. In vitro and in vivo antibacterial activity of ethanolic extract of sweet basil (Ocimum basilicum L.) leaves against Escherichia coliin experimentally Infected Rats Adv Anim Vet Sci,2015; 3: 308-320.

Lambert PA. Mechanisms of antibiotic resistance in Pseudomonas aeruginosa. J R Soc Med, 2002; 95: 22-6.

Limsuwan S, Kayser O, Voravuthikunchai SP. Antibacterial activity of Rhodomyrtus tomentosa (Aiton) Hassk. leaf extract against clinical Isolates of Streptococcus pyogenes. Evid Based Complement Alternat Med, 2012; 697183-6.

NCCLS. Performance standards for antimicrobial susceptibility testing: Ninth information supplement. NCCLS document M100-S9. 2008. Wayne, PA: National Committee for Clinical Laboratory Standard.

Mun SH, Joung DK, Kim SB, Park SJ, Seo YS, Gong R. The mechanism of antimicrobial activity of sophora flavanone B against methicillin-resistant Staphylococcus aureus. Foodborne Pathog Dis,2014; 3: 234-9.
Oonmetta-aree J, Suzuki T, Gasaluck P, Eumkeb G. Antimicrobial properties and action of galangal (Alpinia galanga Linn.) on Staphylococcus aureus. LWT.2006; 39: 1214-1220.

Saxena A, Bawa AS, Raju PS. Phytochemical changes in freshcut jackfruit (Artocarpus heterophyllus L.) bulbs during modified atmosphere storage. Food Chem, 2009; 115: 1443-1449.

Septama AW, Panichayupakaranant P. Antibacterial assayguided isolation of active compounds from Artocarpus heterophyllus heartwoods. Pharm Biol, 2015; 53: 1608-13.

Septama AW, Xiao J, Panichayupakaranant P. A synergistic effect of artocarpanone from Artocarpus heterophyllus L. (Moraceae) on the antibacterial activity of selected antibiotics and cell membrane permeability. J Intercult Ethnopharmacol, 2017, 6(2): 186-191.

Simoes M, Bennet RN, Rosa EAS. Understanding antimicrobial activities of phytochemicals against multidrug resistant bacteria and biofilms. Nat Pro Rep,2009; 26:746-757.

Tsuchiya H, Iinuma M. Reduction of membrane fluidity by antibacterial sophoraflavanone $\mathrm{G}$ isolated from Sophora exigua. Phytomedicine, 2000; 7: 161-5.

World Health Organization State of the art of new vaccine: Research and development diarrheal diseases. WHO.2005. Geneva, Switzerland.

\section{How to cite this article:}

Septama AW, Panichayupakaranant P. Antibacterial activity of artocarpanone isolated from Artocarpus heterophyllus heartwoods against diarrheal pathogens and its mechanism of action on membrane permeability. J App Pharm Sci, 2017; 7 (11): 064-068. 